\title{
LUAS LAHAN DAN PEMENUHAN KEBUTUHAN DASAR (Kasus Rumahtangga Petani Miskin di Daerah Dataran Tinggi Kabupaten Kepahiang)
}

\author{
Area of Land Ownership and Farmers' Basic Needs \\ (Case Study of Poor Farmers at Hilly Area in Kepahiang Dstrict, \\ Province of Bengkulu)
}

\author{
Bahrin, Basita G. Sugihen, Djoko Susanto dan Pang S Asngari
}

\begin{abstract}
The mayority of the poor farmers have relativity enough land, approximately $1 \mathrm{Ha}$ per household. Their poverty is considered as relatively poor. There were four factors which make the poor farmers hardly overcome their problems, namely: working pattern which mostly rely on physical potency; low level of adoption of innovation; poverty trap bounding and low competence to manage opportunity and potency. The poor farmers have to be motivated to get involve in learning process. By doing this approach it is hoped that the farmers could change to get better, more effective dan more productive in land use.
\end{abstract}

Keyword: poor farmers, land, behavior, basic needs

\section{Pendahuluan}

Tanah (lahan) bagi petani merupakan faktor produksi yang sangat penting. Tanah merupakan sumber pendapatan untuk kelangsungan hidup. Luas pemilikan dan penguasaan lahan merupakan salah satu faktor utama yang menentukan tingkat penda-patan suatu keluarga atau rumahtangga petani. Oleh karena itu, ketiadaan atau sempitnya pemilikan dan penguasaan lahan merupakan awal terjadinya kemiskinan di pedesaan, seperti yang umumnya terjadi pada kemiskinan di pedesaan Jawa.

Sajogyo (1984), Chayanov (Tjondronegoro, 1984) mengemukakan bahwa luas pemilikan tanah adalah salah satu faktor penentu untuk peluang berusaha dan bekerja bagi petani. Singarimbun dan Effendi (1989) menambahkan bahwa tingkat pendapatan usahatani di antaranya dipengaruhi oleh luas tanah dan jenis tanaman. Menurut Tan (1991) tingkat pendapatan usahatani ditentukan oleh luas tanah yang dimiliki, yang mencakup luas tanah pemilikan dan luas tanah usahatani.

Pemilikan dan penguasaan merupakan dua hal yang berbeda; "pemilikan menunjuk kepada penguasaan formal, sedangkan penguasaan menunjuk kepada aspek efektifitas. Misalnya, jika sebidang tanah disewakan kepada orang lain, maka orang lain itulah yang secara efektif menguasainya (Wiradi dan Tjondronegoro, 1984).

Berdasarkan pengertian tersebut berarti, seseorang yang memiliki tanah, ia dapat sekaligus sebagai orang yang menguasai tanah tersebut. Tetapi, dapat juga ia memi-liki namun tidak menguasai, karena ia sewakan kepada orang lain. Dengan demikian, seseorang yang memiliki dapat sekaligus sebagai penguasa, sebaliknya seseorang yang menguasai sebidang tanah belum tentu ia sebagai pemiliknya. Orang yang memiliki dan sekaligus menguasai tentu akan lebih baik dari 
orang yang menguasai tapi tidak memiliki. Karena, bagi orang yang memiliki dan sekaligus menguasai, seluruh hasil yang diperoleh hanya untuk dirinya sendiri. Lain halnya dengan orang yang menguasai tapi bukan pemilik (penyewa, bagi hasil dsb.), ia harus membayar sewa atau menyerahkan sebagian hasil kepada pemilik lahan.

Dengan demikian, pemilikan dan atau penguasaan lahan yang luas bukanlah merupakan satu-satunya yang menentukan tingkat kesejahteraan suatu keluarga atau rumahtangga. Lahan yang luas jika tidak dikelola atau diusahakan tidak dapat memberikan hasil yang optimal bagi pemiliknya, apalagi jika dibiarkan terlantar, tidak diusahakan. Sebaliknya, penguasaan yang luas jika bukan sebagai pemilik melainkan penyewa atau bagi hasil juga tidak dapat memperoleh hasil atau keuntungan yang optimal, karena sebagian hasil harus dialokasikan untuk membayar sewa atau diserahkan kepada pemilik lahan, apalagi dengan sewa yang mahal atau sistem bagi hasil yang kurang mencerminkan unsur keadilan antara si penggarap dan pemilik lahan. Oleh karena itu, suatu lahan dapat memberikan hasil yang optimal bagi suatu keluarga atau rumahtangga jika lahan tersebut milik sendiri dan diusahakan sendiri.

Suatu keluarga atau rumahtangga petani yang memiliki dan menguasai lahan yang cukup luas mestinya akan dapat memenuhi berbagai kebutuhan dasar rumahtangganya secara memadai. Tetapi di Provinsi Bengkulu menunjukkan kenyataan yang berbeda. Berbagai hasil penelitian (Zulyan dkk., 2002, Bahrin, 1996, Thamrin, 1991) menunjuk-kan bahwa rata-rata rumahtangga miskin memiliki lahan lebih dari dua hektar. Mengapa mereka miskin? Tulisan ini mencoba mencari jawabannya dan menyoroti keterkaitan antara luas pemilikan dan penguasaan lahan dengan pemenuhan kebutuhan dasar rumahtangga petani miskin di daerah dataran tinggi Kabupaten Kepahiang, sedangkan untuk kasus Kabupaten Seluma sebagai daerah dataran rendah disajikan khusus pada artikel terpisah.

\section{Metode Penelitian}

Penelitian ini didesain sebagai penelitian yang bersifat deskriptif- korelasional dengan menggunakan metode survey. Penentuan lokasi penelitian dilakukan secara ber-tahap berdasarkan pembagian zona wilayah, mengacu kepada Peraturan Daerah Nomor 65 Tahun 2006. Wilayah Provinsi Bengkulu dapat dibagi atas dua zona, yaitu: Zona 1 adalah zona dataran rendah yang membentang di sepanjang pantai, dari Kabupaten Kaur sampai ke Kabupaten Mukomuko, yang meliputi kabupaten: Kaur, Bengkulu Selatan, Seluma, Kota Bengkulu, Bengkulu Utara dan Mukomuko; dan Zona 2 adalah zona dataran tinggi, dengan kemiringan di atas $15 \%$, yang meliputi kabupaten: Kepahiang, Rejang Lebong dan Lebong.

Penelitian dilakukan di Kabupaten Kepahiang sebagai kabupaten yang mewakili daerah dataran tinggi. Pemilihan kabupaten sebagai lokasi penelitian dilakukan secara acak melalui undian. Sebelum dilakukan pemilihan, terlebih dahulu dikeluarkan kota Bengkulu dengan pertimbangan bahwa fokus penelitian ini adalah rumahtangga petani miskin dan di Kota Bengkulu mayoritas penduduk miskin bukan petani.

Populasi berjumlah 35423 rumahtangga miskin Besar sampel ditentukan dengan menggunakan rumus Slovin dengan batas eror $6,5 \%$. Besarnya alokasi sampel pada masingmasing kabupaten ditentukan dengan mempertimbangkan porsi jumlah penduduk miskin serta kepentingan pengolahan data. Di Kabupaten Kepahiang diambil dua kecamatan dan masing-masing kecamatan diambil dua desa sebagai sampel tempat pelaksanaan penelitian. Di tiap desa diambil 25 rumahtangga, jumlah sampel 100 rumahtangga. Pengambilan sampel rumahtangga petani miskin dilakukan secara acak.

Data primer diperoleh dengan mendatangi dan melakukan wawancara terhadap responden dengan berpedoman pada kuesioner. Kuesioner yang digunakan terlebih 
dahulu sudah diuji tingkat validitas dan reliabilitasnya. Data primer juga dilengkapi dengan wawancara mendalam, baik terhadap responden maupun terhadap pemimpin formal dan informal setempat.

Analisis data dilakukan secara deskriptif dan kuantitatif. Analisis deskriptif ditujukan untuk mendeskripsikan data yang bersifat deskriptif. Analisis kuantitatif dilakukan untuk uji hipotesisi (hubungan antar peubah) dengan menggunakan uji statistika. Analisis statistika yang dilakukan meliputi: (1) Analisis statistika deskriptif, (2) Analisis korelasi , dan (3) Analisis regresi berganda.

\section{Hasil dan Pembahasan}

\section{Luas Pemilikan dan Penguasaan Lahan}

Rumahtangga petani miskin di Kabupaten Kepahiang umumnya memiliki dan atau menguasai lahan yang cukup luas, terutama lahan daratan. Setiap rumahtangga rata-rata memiliki atau menguasai lahan pekarangan 0,0877 hektar, dan lahan daratan 1,205 hektar. Di antara 100 rumahtangga petani miskin, yang memiliki lahan sawah sebanyak $38 \%$ dengan luas rata-rata 0,43 hektar. Sebanyak $62 \%$ lainnya tidak memiliki lahan sawah, mereka mengusahakan lahan sawah dengan cara menumpang atau menyewa/ kontrak. Keadaan tingkat pemilikan dan penguasaan lahan rumahtangga petani miskin di lokasi penelitian disajikan pada Tabel1.

Sebagian besar (68\%) rumahtangga petani miskin di Kabupaten Kepahiang memiliki lahan pekarangan, dengan status kepemilikan ; bersertifikat sebanyak (15\%) dan hak milik adat sebanyak (53\%). Luas lahan pekarangan yang dimiliki sebagian besar $(92 \%)$ berkisar antara $100-2500 \mathrm{~m}^{2}$. Di antara 100 rumahtangga petani miskin terdapat (30\%) yang menempati lahan pekarangan dengan status menumpang. Mereka men-dirikan rumah/ tempat tinggal dengan menumpang pada lahan pekarangan milik kerabat. Umumnya masih ada pertalian hubungan darah, misalnya anak, saudara atau keponakan. Jangka waktunya, ada yang dibatasi dan ada yang tidak. Namun ada pula yang langsung menjadi hak milik, baik melalui pemberian maupun dibeli dengan cara mencicil.

Lahan daratan yang biasanya digunakan untuk menanam padi ladang, palawija, atau tanaman perkebunan, sebagian besar (70\%) merupakan milik sendiri, dengan status kepemilikan: bersertifikat sebanyak (3\%) dan hak milik adat sebanyak (67\%). Luas lahan daratan yang dimiliki atau dikuasai sebagian besar $(73 \%)$ berkisar antara 0,69 sampai dengan 1,56 hektar. Di antara 100 rumahtangga petani miskin terdapat (20\%) menguasai lahan daratan dengan cara menumpang dan (10 \%) dengan cara menyewa atau kontrak.

Rumahtangga yang berstatus menumpang, umumnya kerabat dekat dan kebanyakan adalah hubungan antara anak dan orangtua atau saudara, sedangkan yang menyewa atau kontrak umumnya jarang dari kerabat dekat seperti yang menumpang. Kalaupun mem-punyai hubungan garis keturunan, tapi sudah jauh atau bahkan tidak mempunyai hubungan kerabat sama-sekali. Jenis komoditas perkebunan yang ditanam umumnya kopi. Pola usahatani yang dilakukan lebih banyak bersifat monokultur.

Rumahtangga petani miskin di Kepahiang yang memiliki lahan sawah sebanyak (28\%), dengan status kepemilikan: bersertifikat $10 \%$ dan hak milik adat $18 \%$. Selebihnya, yakni sebanyak (72\%) tidak memiliki lahan sawah. Luas lahan sawah yang dimiliki atau dikuasai sebagian besar $(92 \%)$ berkisar antara 0,20 sampai dengan 0,64 hektar, dengan luas rata-rata 0,43 hektar. Di antara 100 rumahtangga petani miskin terdapat $(21 \%)$ yang menguasai lahan sawah dengan cara menumpang dan (51\%) dengan cara menyewa atau kontrak. Sebagai daerah dataran tinggi, areal persawahan di Kabupaten Kepahiang relatif sempit. Di daerah ini tidak ada jaringan irigasi besar yang dibangun pemerintah. 
Tabel 1. Pemilikan dan penguasaan lahan rumahtangga petani miskin

\begin{tabular}{|c|c|}
\hline Jenis lahan, Luas dan Status Kepemilikan & Persentase \\
\hline Lahan Pekarangan : & \\
• Luas : $<2500 \mathrm{~m}^{2}$ & 92,00 \\
$2500-5000 \mathrm{~m}^{2}$ & 3,00 \\
$5001-7500 \mathrm{~m}^{2}$ & 0 \\
$7501-10.000 \mathrm{~m}^{2}$ & 5,00 \\
- Status Kepemilikan: & 15,00 \\
Sertifikat & 53,00 \\
Hak milik adat & 2,00 \\
Sewa/kontrak & 30,00 \\
Menumpang & \\
- Luas: & 15,00 \\
0,25 - 0,68 Ha & 33,00 \\
0,69 - 1,12 Ha & 40,00 \\
1,13 - 1,56 Ha & 12,00 \\
1,57 - 2,00 Ha & 3,00 \\
- Status Kepemilikan: & 67,00 \\
Sertifikat & 10,00 \\
Hak milik adat & 20,00 \\
Sewa/kontrak & \\
Menumpang & 92,00 \\
- Status Kepemilikan: & 8,00 \\
Sertifikat & 10,00 \\
Hak milik adat & 18,00 \\
Sewa/kontrak & 51,00 \\
Menumpang & 21,00 \\
\hline & \\
0,20 - 0,64 Ha & \\
\hline Lahan Sawah: & \\
\hline
\end{tabular}

Rumahtangga petani miskin di Kepahiang yang memiliki lahan sawah sebanyak (28\%), dengan status kepemilikan: bersertifikat $10 \%$ dan hak milik adat $18 \%$. Selebihnya, yakni sebanyak (72\%) tidak memiliki lahan sawah. Luas lahan sawah yang dimiliki atau dikuasai sebagian besar $(92 \%)$ berkisar antara 0,20 sampai dengan 0,64 hektar, dengan luas rata-rata 0,43 hektar. Di antara 100 rumahtangga petani miskin terdapat $(21 \%)$ yang menguasai lahan sawah dengan cara menumpang dan $(51 \%)$ dengan cara menyewa atau kontrak. Sebagai daerah dataran tinggi, areal persawahan di Kabupaten Kepahiang relatif sempit. Di daerah ini tidak ada jaringan irigasi besar yang dibangun pemerintah.

Berdasarkan paparan di atas memperlihatkan bahwa $70 \%$ rumahtangga petani miskin menguasai lahan daratan milik sendiri, dengan luas rata-rata 1,201 hektar. Hal itu menunjukkan bahwa rumahtangga petani miskin di daerah ini pada dasarnya mem-punyai potensi sumberdaya ekonomi (lahan) yang cukup memadai untuk memperbaiki kondisi kehidupan keluarga atau rumahtangganya. Jika lahan tersebut dapat dikelola dan dimanfaatkan dengan baik, serta hasilnya dapat dikelola dengan baik akan dapat memenuhi kebutuhan dasar 
rumahtangga mereka atau bahkan dapat melepaskan mereka dari lilitan kemiskinan.

\section{Pemenuhan Kebutuhan \\ Dasar Rumahtangga}

Konsep kebutuhan rumahtangga yang dipakai dalam penelitian ini adalah konsep pemenuhan hak-hak dasar. Oleh karena itu. Pemenuhan kebutuhan rumahtangga adalah meliputi pemenuhan kebutuhan-kebutuhan: pangan, perumahan, air bersih, pendidikan, kesehatan, lapangan pekerjaan dan kesempatan berusaha, dan kebutuhan akan rasa aman. Keadaan tingkat pemenuhan kebutuhan rumahtangga petani miskin di lokasi penelitian disajikan pada Tabel 2

Tabel 2. Pemenuhan kebutuhan rumahtangga petani miskin

\begin{tabular}{|l|l|c|}
\hline \multicolumn{1}{|c|}{ Jenis Kebutuhan } & \multicolumn{1}{|c|}{ Kategori Pemenuhan } & Persentase \\
\hline Pangan & Baik & 5,00 \\
& Cukup & 44,00 \\
& Kurang & 51,00 \\
\hline Perumahan & Layak & 7,00 \\
& Cukup Layak & 27,00 \\
& Kurang layak & 48,00 \\
& Sangat tidak layak & 18,00 \\
\hline Air bersih & Baik & 3,00 \\
& Cukup & 97,00 \\
\hline Akses Layanan Pendidikan Dasar Anggota & Tinggi & 42,00 \\
Rtm & Sedang & 49,00 \\
& Kurang & 7,00 \\
& Sangat kurang & 2,00 \\
\hline Akses Layanan Kesehatan & Baik & 5,00 \\
& Cukup & 73,00 \\
& Kurang & 19,00 \\
& Sangat kurang & 3,00 \\
\hline Akses Lapangan Pekerjaan & Baik & 2,00 \\
& Kurang & 85,00 \\
& Sangat kurang & 13,00 \\
\hline Kebutuhan akan Rasa Aman & Sangat aman & 27,00 \\
& Aman & 66,00 \\
& Kurang aman & 7,00 \\
\hline
\end{tabular}

Sebagian besar rumahtangga petani miskin di Kepahiang (51\%) tingkat pemenuhan kebutuhan pangan keluarganya termasuk pada kategori kurang. Mereka umumnya makan nasi antara satu sampai dua kali sehari dengan porsi yang kurang, terutama pada saat paceklik menjelang musim panen kopi. Walaupun porsi makan nasi termasuk kurang, namun umumnya mereka mampu mengkonsumsi ikan minimal tiga kali seminggu, karena ikan bagi mereka mudah untuk mendapatkannya.

Ikan mereka peroleh dengan memancing, memasang bubu atau jaring di sungai atau di sawah. Di antara 100 rumahtangga petani miskin terdapat (44\%) tingkat pemenuhan kebutuhan pangannya pada kategori cukup dan (5\%) pada kategori baik.

Kondisi rumah petani miskin sebagian besar $(66 \%)$ kurang layak dan sangat tidak layak, terutama dilihat dari segi atap, dinding, lantai dan luas lantai. Dilihat dari jenis dinding terluas, sebagian besar (54\%) adalah bambu/pelupuh. Atap rumah, sebagian besar (92\%) adalah seng, namun kondisinya sudah hitam dan banyak yang bocor dan sebagian merupakan seng bekas. Sebanyak (49\%) rumah petani miskin berlantai semen, namun ada $(47 \%)$ yang berlantai tanah atau bambu. Dilihat dari luas lantai, sebagian besar $(60 \%)$ berkisar antara $16 \quad-37 \quad \mathrm{~m}^{2}$, dan jika dihubungkan dengan standar luas lantai $8 \mathrm{~m}^{2}$ 
Tabel 3. Jumlah petani miskin menurut kondisi rumah di Kabupaten Kepahiang

\begin{tabular}{|l|l|c|}
\hline Kondisi Rumah & Kategori & Persentase \\
\hline Jenis Dinding Terluas & Tembok/beton & 29,00 \\
& Bata merah & 17,00 \\
& Bambu & 54,00 \\
\hline Jenis Atap Terluas & Genteng beton/tanah & 4,00 \\
& Sirap/asbes & 4,00 \\
& Seng & 92,00 \\
\hline Jenis Lantai Terluas & Semen & 49,00 \\
& Papan & 4,00 \\
& Bambu atau tanah & 47,00 \\
\hline Luas Lantai & $49-60 \mathrm{~m}^{2}$ & 20,00 \\
& $38-48 \mathrm{~m}^{2}$ & 20,00 \\
& $27-37 \mathrm{~m}^{2}$ & 14,00 \\
& $16-26 \mathrm{~m}^{2}$ & 46,00 \\
\hline
\end{tabular}

per jiwa, maka sebagian besar rumah/tempat tinggal petani miskin di sini tidak memenuhi standard tersebut. Sebaran jumlah petani miskin dilihat dari kondisi rumah disajikan pada Tabel 3.

Tingkat pemenuhan kebutuhan air bersih sebanyak (97\%) pada kategori cukup. Untuk air minum, memasak makanan maupun untuk mandi dan mencuci umumnya digunakan air sumur atau mata air. Air sumur yang digunakan umumnya tidak ditutup, tetapi dibiarkan terbuka dan pengambilan air kebanyakan dilakukan dengan menggunakan timba yang memakai derek. Pemenuhan kebutuhan air bersih umumnya cukup baik.

Pemenuhan hak atas layanan pendidikan dasar bagi anggota rumahtangga sebagian besar $(91 \%)$ tergolong sedang dan tinggi.
Artinya sekitar (91\%) anggota rumahtangga petani miskin di daerah ini mampu menikmati layanan pendidikan dasar. Dilihat dari pendidikan tertinggi anggota keluarga sebagian besar (53\%) tamat sekolah dasar (SD). Angka partisipasi pendidikan dasar anggota rumahtangga petani miskin sebagian besar $(65 \%)$ berkisar antara $(76-100 \%)$. Artinya, dari 100 rumahtangga petani miskin, seba-nyak (65\%) yang anggota rumahtangganya antara $76-100 \%$ dapat menyelesaikan pendidikan dasar. Angka drop out pendidikan dasar sebagian besar $(76 \%)$ kurang dari $26 \%$. Kondisi tingkat pemenuhan hak memperoleh layanan pendidikan rumahtangga petani miskin di lokasi penelitian disajikan pada Tabel 4 .

Tabel 4. Pemenuhan hak memperoleh pendidikan bagi anggota rumahtangga

\begin{tabular}{|l|l|c|}
\hline \multicolumn{1}{|c|}{ Parameter } & Kategori & Persentase \\
\hline Pendidikan Tertinggi Anggota Rmt & SLTA & 25,00 \\
& SLTP & 19,00 \\
& SD & 53,00 \\
& Tidak Tamat SD & 3,00 \\
\hline Angka Partisipasi Pendidikan Dasar & $76-100 \%$ & 65,00 \\
& $51-75 \%$ & 24,00 \\
& $26-50 \%$ & 11,00 \\
& $<26 \%$ & 0 \\
\hline Angka Drop Out Pendidikan Dasar & $<26 \%$ & 76,00 \\
& $26-50 \%$ & 5,00 \\
\hline
\end{tabular}


Akses rumahtangga petani miskin terhadap layanan kesehatan sebagian besar (73\%) pada kategori cukup. Artinya bahwa sebagian besar rumahtangga miskin di daerah ini mampu memperoleh layanan kesehatan bagi anggota rumahtangganya yang sakit. Dilihat dari tingkat kematian balita tergolong rendah, yakni sebesar 13\%. Sebagian besar $(81 \%)$ rumahtangga petani miskin di lokasi penelitian berobat di Puskesmas, bila ada anggota keluarganya yang sakit. Tingkat kematian balita dan tempat berobat bagi anggota rumahtangga petani miskin di sajikan pada Tabel 5

Tabel 5. Tingkat kematian balita dan tempat berobat bagi anggota rumahtangga petani miskin

\begin{tabular}{|l|l|c|}
\hline Parameter & Kategori & Persentase \\
\hline Angka Kematian Balita & Tidak ada & 87,00 \\
& Satu Orang & 10,00 \\
& > Satu Orang & 3,00 \\
\hline Tempat Berobat & Dokter Praktek & 4,00 \\
& Rumah Sakit & 1,00 \\
& Puskesmas & 81,00 \\
& Dukun & 14,00 \\
\hline
\end{tabular}

Akses rumahtangga petani miskin terhadap lapangan pekerjaan dan kesempatan berusaha di luar usahatani yang dilakukannya, sebagian besar (98\%) kurang dan sangat kurang. Hal ini diduga terkait dengan tingkat pendidikannnya (formal dan non formal) rendah, tingkat akses terhadap informasi rendah, serta akses pasar dan akses terhadap sumber modal juga rendah. Dengan demikian kemampuan untuk melihat dan meman-faatkan peluang serta potensi yang ada juga rendah. Pola kerja dan usaha yang dilakukan lebih mengandalkan kekuatan otot dan mengikuti pola yang sudah bersifat turuntemurun. Informasi untuk bekerja sebagai buruh tani harian biasanya diperoleh dari mulut ke mulut dan umumnya terbatas di lingkungan tempat tinggal (desa).

Kondisi keamanan yang dirasakan rumahtangga petani miskin, baik di sekitar tempat tinggal maupun keamanan terhadap tindak pencurian terhadap hasil usahatani yang dilakukan, sebagian besar (93\%) merasa aman dan sangat aman. Namun sebanyak (7\%) lainnya merasa kurang aman. Hal ini menunjukkan bahwa dari aspek keamanan cukup kondusif bagi sebagian besar warga untuk melaksanakan berbagai aktivitas bagi kelangsungan hidupnya. Sebagian kecil penduduk yang merasa kurang aman terutama dari tindak pencurian.

\section{Pembahasan}

Berdasarkan paparan tentang kondisi luas pemilikan dan penguasaan lahan dan tingkat pemenuhan kebutuhan dasar rumahtangga petani miskin di atas, menunjukan bahwa kemiskinan yang terjadi di daerah ini lebih kepada kemiskinan relatif. Walaupun demikian ada sebagian kecil yang cenderung pada kemiskinan absolut yakni yang lahannya sempit. Tingkat kemampuan rumahtangga miskin di daerah ini dalam memenuhi kebutuhan dasar umumnya rendah. Rumahtangga petani miskin umumnya memiliki dan menguasai lahan daratan yang cukup luas. Namun tingkat pemenuhan kebutuhan dasar, khususnya pangan dan perumahan sebagian besar masih rendah. Mengacu kepada pendapat Sen (1982) orang miskin bukan karena tidak memiliki sesuatu, melainkan karena tidak dapat melakukan sesuatu untuk memperbaiki kondisi kehidupannya.

Hasil analisis korelasi Spearman anatara luas pemilikan dan penguasaan lahan dengan pendapatan rumahtangga menunjukkan tidak terdapat hubungan yang nyata dengan koefisien korelasi sebesar 0,1251. Hal ini berarti bahwa pemilikan dan pengua-saan lahan yang luas tidak secara otomatis tingkat pendapatannya juga tinggi, atau sebaliknya. 
Secara teoritis, petani yang memiliki dan menguasai lahan yang luas akan mempunyai pendapatan yang lebih tinggi dibandingkan petani yang berlahan sempit, karena luas pemilikan dan penguasaan lahan merupakan faktor utama yang mempengaruhi tingkat pendapatan petani, seperti dikemukakan oleh Sajogyo (1989), Tan (1991) dan Singarimbun dan Effendi (1989). Tetapi di sini faktanya menunjukkan bahwa walaupun mereka memiliki dan menguasai lahan yang cukup luas, namun mereka masih termasuk miskin.

Fakta tersebut menunjukan bahwa lahan yang luas belum mampu memberi kontri-busi yang besar terhadap tingkat produksi dan pendapatan petani pemilik atau yang menguasainya. Artinya tingkat produktivitas lahan tersebut rendah, karena jika suatu rumahtangga memiliki dan menguasai lahan daratan satu hektar dan lahan tersebut ditanami kopi, pada panen perdana usia tanam empat sampai enam tahun bisa menghasilkan kopi antara 1,5 sampai 3,0 ton per musim panen. Saat penelitian dilakukan, harga kopi berkisar antara Rp 12.000,- sampai Rp 15.000,- per kg. Bila satu hektar menghasilkan 1,5 ton, dengan harga $\mathrm{Rp}$ 12.000,-, maka pendapatan kotor yang bisa diperoleh adalah Rp 18.000.000,-. Ongkos giling dan ongkos angkut $\mathrm{Rp} 1000$ per $\mathrm{kg}$, maka pendapatan bersih yang bisa diterima adalah sebesar Rp 16.500.000,-per musim panen. Dengan demikian, pendapatan per bulan dari hasil panen puncak adalah sebesar Rp 1.375.000,-, Hasil ini baru hasil saat puncak musim panen, selain itu juga ada hasil panen sela setiap bulannya yang jumlahnya tergantung pada umur tanaman dan perawatan.

Pada kebun kopi yang kondisinya baik, hasilnya bisa mencapai lebih dari $20 \mathrm{~kg}$ per bulan. Bila kita ambil saja rata-rata $20 \mathrm{~kg}$ per bulan, maka berarti hasil yang bisa didapat per bulannya adalah sebesar Rp 240.000,-,. Dengan demikian, hasil total perbulan yang bisa didapat petani adalah sebesar Rp 1.615.000,. Mengacu kepada garis kemiskinan U\$ 1 per kapita per hari, dan dengan jumlah anggota rumahtangga rata-rata 5 orang, maka berarti pendapatan per kapita jauh di atas garis kemiskinan tersebut.

Pertanyaannya, mengapa produktivitas lahan mereka rendah? Ada beberapa faktor penyebabnya. Pertama; lahan luas yang mereka miliki belum dikelola dan dimanfaatkan secara optimal (intensif), sehingga tingkat produktivitasnya rendah. Usahatani yang dilakukan, khususnya padi masih bersifat subsisten. Lahan sawah, walaupun airnya tersedia sepanjang tahun tetapi kebanyakan ditanami sekali setahun. Lahan daratan umumnya ditanami kopi. Usahatani kopi dilakukan mengikuti kebiasaan yang sudah bersifat turun-temurun, umumnya belum mendapat sentuhan teknologi, seperti pemupukan, penanganan pembibitan yang standar atau pembuatan teras siring. Adopsi inovasi rendah. Pola kerja dan usaha mengikuti pola yang sudah bersifat turun-temurun. Komoditas usahatani yang ditanam bukan didasarkan atas permintaan pasar, tetapi lebih pada kebiasaan. Pola usahatani lebih bersifat monokultur.

Kedua: harga produk usahatani, khususnya sektor tanaman pangan tidak sebanding dengan harga produk industri yang sudah menjadi kebutuhan rumahtangga petani, seperti; minyak goreng, minyak tanah, susu, pakaian, sabun mandi, pasta gigi, biaya sekolah (alat tulis, buku dan pakaian seragam) dan sebagainya. Minyak goreng, misalnya; harga di pedesaan mencapai Rp 10.000,- per $\mathrm{kg}$, jika dibandingkan dengan harga beras saat musim panen berkisar antara Rp 2000,sampai Rp 3000,- per kg, apalagi bila dibandingkan dengan harga sayur-sayuran ; seperti kubis, kacang buncis, sawi dan sebagainya. Untuk membeli $1 \mathrm{~kg}$ minyak goreng berarti mereka harus menjual $3-5 \mathrm{~kg}$ beras. Apalagi jika komoditas yang ditanam selain padi bukan didasarkan atas permintaan pasar, harganya dapat berfluktuasi.

Ketiga: jebakan kemiskinan seringkali membuat kemampuan sumberdaya keluarga terpecah, tidak dapat dialokasikan secara penuh pada upaya pemanfaatan lahan milik sendiri, melainkan harus dibagi untuk menjadi buruhtani harian guna memenuhi kebutuhan 
pangan keluarga. Semakin besar tingkat kekurangan pangan keluarga yang harus ditanggung semakin banyak alokasi sumberdaya (tenaga kerja) yang harus digunakan untuk menjadi buruh harian, dan itu berarti semakin sedikit peluang untuk mengelola dan mengurus lahan miliknya sendiri. Akibatnya lahan milik sendiri tidak tergarap atau tidak terkelola dengan baik, sehingga produktivitasnya rendah dan tingkat pendapatan dari usahatani milik sendiri juga rendah. Dengan demikian tingkat ketergantungannya untuk menjadi buruhtani harian semakin besar dan kemampuan untuk mengelola dan memanfaatkan lahan milik sendiri semakin kecil atau terbatas.

Ke empat: rendahnya kemampuan dalam melihat peluang dan potensi yang ada yang dapat diman-faatkan bagi peningkatan produktivitas dan pendapatannya.

Rendahnya tingkat pendidikan (formal dan non formal) dan akses terhadap informasi terutama yang terkait dengan usahatani yang dilakukan menyebabkan tidak terjadinya proses belajar yang efektif pada petani miskin terutama dalam bekerja dan berusaha, seiring dengan terjadinya perubahan yang sangat cepat pada berbagai aspek kehidupan, sehingga perilakunya menjadi kurang efektif dan kurang produktif. Kemampuan melihat peluang usaha dan memanfaatkan berbagai potensi yang ada sangat rendah. Kegagalan atau rendahnya tingkat produksi dan pendapatan yang dicapai tidak dijadikan bahan pelajaran untuk melakukan perbaikanperbaikan atau mencari alternatif-alternatif lain yang dapat dilakukan. Terjadinya perubahan lingkungan strategis mengharuskan terjadinya perubahan perilaku manusianya. Sebagai contoh; terjadinya penurunan tingkat kesuburan tanah, mengharuskan petani untuk melakukan tindakan untuk mengembalikannya melalui pemupukan. Ketika hal itu tidak dilakukan, akibatnya terjadi penurunan produksi dan itu berarti awal terjadinya penurunan tingkat pendapatan.

Masyarakat, khususnya petani harus disadarkan agar mereka mau dan mampu untuk belajar secara terus-menerus agar dapat merespon dan berperilaku secara tepat dalam menghadapi perubahan dalam berbagai aspek kehidupan yang sangat cepat. Dengan cara demikian, mereka akan dapat menemukan dan memanfaatkan peluang dan potensi yang dimiliki bagi kelangsungan hidup keluarga atau rumahtangganya.

Para petani miskin harus berubah dari pola yang bersifat subsisten dan berpikir jangka pendek ke pola pikir dan pola tindak yang bersifat persfektif jangka panjang. Makna tanah (lahan) yang sudah terinternalisasi dalam budaya dan sudah dipahami sebagai sesuatu yang penting dan menjadi simbul status sosial dalam masyarakat, tidak sekedar dilihat dari segi kepemilikan belaka, tetapi harus diarahkan pada bagaimana mengelola dan memanfaatkan lahan tersebut secara optimal agar dapat memberikan manfaat yang sebesarbesarnya bagi peningkatan kesejahteraan.

Persoalannya, bagaimana mengubah pola pikir dan pola budaya yang sudah terinternalisasi dalam benak (kepala) setiap orang atau warga masyarakat khususnya warga miskin? Dalam kaitan ini, maka pendidikan non formal menjadi sangat penting untuk dilaksanakan secara sungguh-sungguh, terencana dan ditangani secara profesional. Tanpa terjadinya proses belajar dalam masyarakat, sulit diharapkan tercapainya peningkatan kesejahteraan dalam masyarakat tersebut secara mandiri dan berkesinambungan. Para petani harus mampu dan cerdas dalam melihat dan menangkap setiap peluang yang dapat dimanfaatkan untuk meningkatkan produktivitas dan pendapatannya.

\section{$\underline{\text { Kesimpulan }}$}

(1) Mayoritas rumahtangga petani miskin di lokasi penelitian memiliki dan atau menguasai lahan yang cukup luas, khususnya lahan daratan.

(2) Tingkat pemenuhan kebutuhan dasar, khususnya pangan, perumahan dan akses terhadap lapangan pekerjaan dan kesempatan berusaha sebagian besar pada 
kategori rendah, sedangkan pemenuhan kebutuhan air bersih, layanan kesehatan , layanan pendidikan dasar bagi anggota keluarga, dan kebutuhan akan rasa aman mayoritas tergolong kategori cukup.

(3) Tingkat kemampuan rumahtangga petani miskin di daerah dataran tinggi Kabupaten Kepahiang dalam memenuhi kebutuhan dasar rendah.

(4) Makna lahan (tanah) sudah dipahami sebagai sesuatu yang penting, tetapi pengetahuan dan kemampuan untuk mengelola dan memanfaatkan lahan tersebut secara produktif masih sangat rendah.

(5) Masyarakat, khususnya warga miskin belum menyadari pentingnya proses belajar guna memperbaiki kualitas perilakunya agar mereka dapat meningkatkan kualitas kehidupan keluarganya.

\section{$\underline{\text { Rujukan }}$}

Sajogyo. 1984. Memahami dan Menanggulangi Kemiskinan di Indonesia. Jakarta: Grasindo.

Sen, A. 1982. Poverty and Famines. Clarendon Press-Oxford.

Sherraden, M. 2006. Aset untuk Orang Miskin. Jakarta: PT. Raja Grafindo Persada.

Singarimbun, M., dan Effendi, S. 1989. Metode Penelitian Survai. Jakarta: LP3ES.

Susanto, Dj. 2006. "Proses Belajar : Tantangan dalam Penelitian Bidang Pembangunan Pendidikan Masyarakat." Diknas: Jurnal Teknodik, No. 19/X/TEKNODIK/Desem- ber/ 2006.

Tan, Melly G. 1991. Perubahan Struktur Sosial di Bengkulu. Yogyakarta: UGM Press.

Wiradi, G., dan Tjondronegoro, S.M.P. 1984. Dua Abad Penguasaan Tanah, Pola Penguasaan Tanah Pertanian di Jawa dari Masa ke Masa. Jakarta: Gramedia. 